\title{
Gas Exchange of Mimosa tenuiflora (Willd.) Poiret Under Water Deficit and Rewatering
}

\author{
Francisco Jose Basilio Alves, Antonio Lucineudo Oliveira Freire (Corresponding Author) \\ Dept. of Forest Engineering, Federal University of Campina Grande, Brazil
}

Received: Aug. 26, 2019

doi:10.5296/jas.v7i4.15338
Accepted: Oct. 29, 2019 Published: Oct. 30, 2019

URL: https://doi.org/10.5296/jas.v7i4.15338

\begin{abstract}
This research aimed to evaluate the physiological responses of Mimosa tenuiflora plants submitted to variable water availability conditions during the nursery stage. Twelve-month-old plants kept in plastic pots containing $5 \mathrm{~kg}$ of the substrate composed of the subsoil soil mixture and bovine manure (2:1) were submitted to two treatments: irrigated (control) and water stress, which was imposed through the suspension of irrigation, rewatering after seven days of stress. The relative water content $(R W C)$ and stomatal parameters were evaluated. The $M$. tenuiflora plants responded quickly to the irrigation suspension, promoting the closure of the stomata, occurring reduction in stomatal conductance, transpiration rate and photosynthesis. The instantaneous efficiency in water use of plants under water deficit remained high only until the middle of the period when irrigation was suspended, and then declined until the last day of the water deficit. After rehydration, the plants showed recovery in all evaluated parameters, indicating that the level of stress imposed did not cause irreversible damages in the cells and tissues.
\end{abstract}

Keywords: water stress, drought tolerance, water relations

\section{Introduction}

Mimosa tenuiflora (Willd.) Poiret.), popularly named 'jurema-preta', is one of the most commonly woody species in the Brazilian semiarid, belonging to the Mimosaceae family. It is native to the Caatinga Biome, but not endemic to the region, and can also be found in northern Venezuela and Colombia and in dry regions of southern Mexico, Honduras and El Salvador (Azevêdo et al., 2012).

It is a species that tolerates droughts well, with a large annual regrowth capacity, and is used as an energy source due to the excellent quality of the wood. In addition, it can favor the regeneration of plants that grow under its canopy, thus contributing to the regeneration of eroded soils, as well as being indicated for ecological restoration programs (Santos et al., 2011, Paterno et al., 2016). 
In tropical regions, droughts are often associated with high solar radiation (Gouvêa and Marenco, 2018) which combined with the low capacity of Caatinga's soils, reduce the water storage capacity of this biome. This situation tends to worsen in the face of global climate change that our planet is going through. In their review of climate projections on the Brazilian Northeast, citing some authors, Guimarães et al. (2016) report that this is a region with considerable vulnerability to climate change and is subject to changes in the distribution of extreme events, summer events, spatial distribution of rainfall, etc. Hence the need for a better understanding of the physiological strategies developed by the plants of this region to survive under these conditions.

Plant species that inhabit semiarid climate regions respond to water deficit by developing strategies and/or mechanisms for escape or drought tolerance (Araújo, 2005). Because they are subject to long periods of drought, changes occur in physiological, biochemical, molecular and morphological processes due to reduced leaf water potential. Among these physiological modifications, stomata closure assumes a prominent position, causing reduction in stomatal conductance, transpiration and photosynthesis rate, causing a decrease in plant growth (Chaves et al., 2003, Fernandes et al., 2015). In addition, there is a decrease in protective protein synthesis (Choudhury et al., 2017), and as a survival strategy plants can promote osmotic adjustment by accumulation of osmotically compatible solutes, ensuring the maintenance of cell turgidity, avoiding tissue death (Sircelj et al., 2007, Nio et al., 2011).

Several researchers have developed research to evaluate the effects of water deficit on gas exchange in forest species (Costa et al., 2015, Oliveira et al., 2016, Moura et al., 2016, Oliveira and Gualtieri, 2017). However, there is little research with native plants of Caatinga on this subject, and more research is needed to provide this information.

In this sense, this aimed to evaluate the physiological and biochemical responses of black jurema plants submitted to progressive water deficit and subsequent rewatering.

\section{Material and Methods}

\subsection{Plant Growth: Experimental Design}

This study took placed in nursery conditions of the Forest Engineering Department, Federal University of Campina Grande, Patos, Paraiba State, Brazil ( $7^{\circ} 03^{\prime} 34^{\prime \prime} \mathrm{S}$ and $37^{\circ} 16^{\prime} 30^{\prime \prime} \mathrm{W}$, and $242 \mathrm{~m}$ elevation).

Seeds of $M$. tenuiflora were subjected to integumentary dormancy break according to Bakke et al. (2006) and then placed to germinate in conical tubes $\left(125 \mathrm{~cm}^{3}\right)$ containing the substrate composed of subsoil and cattle manure mixture, 2: 1 ratio. The soil used was analyzed both chemical and physical properties (Table 1). Thirty days after emergence, the seedlings were transferred to plastic pots containing $5 \mathrm{~kg}$ of the above substrate. Irrigation was performed daily, trying to keep the substrate humidity close to $70 \%$ of the retention capacity, determined by weighing.

The plants were kept in this condition until they reached one year of age, when were separated into two groups, in which one group continued to be normally irrigated (irrigated 
treatment) and the other had suspended irrigation (water deficit treatment).

The treatment of water stress persisted until it was realized that the photosynthesis $(A)$ reached values close to zero, which happened on the seventh day after irrigation interruption. After this, the water supply to the plants resumed, until the photosynthesis rate of the water stress treatment plants reached values close to those observed in the control treatment plants, which occurred three days after rehydration.

Table 1. Chemical and chemical properties of soil used

\begin{tabular}{lll}
\hline Chemical analysis & Unity & Value \\
\hline $\mathrm{pH}\left(\mathrm{CaCl}_{2} 0,01 \mathrm{M}\right)$ & \multicolumn{1}{c}{-} & 5,0 \\
$\mathrm{P}$ & $\mu \mathrm{g} \mathrm{dm}^{-3}$ & 4,5 \\
$\mathrm{Ca}$ & $\mathrm{cmol}_{\mathrm{c}} \mathrm{dm}^{-3}$ & 5,1 \\
$\mathrm{Mg}$ & $\mathrm{cmol}_{\mathrm{c}} \mathrm{dm}^{-3}$ & 1,9 \\
$\mathrm{~K}$ & $\mathrm{cmol}_{\mathrm{c}} \mathrm{dm}^{-3}$ & 0,17 \\
$\mathrm{Na}$ & $\mathrm{cmol}_{\mathrm{c}} \mathrm{dm}^{-3}$ & 0,57 \\
$\mathrm{H}+\mathrm{Al}$ & $\mathrm{cmol}_{\mathrm{c}} \mathrm{dm}^{-3}$ & 3,1 \\
$\mathrm{CTC}$ & $\%$ & 10,84 \\
$\mathrm{~V}$ & $\%$ & 71,4 \\
\hline Physical analysis & & \\
\hline Sand & $\mathrm{g} \mathrm{kg}^{-1}$ & 780 \\
Silt & $\mathrm{g} \mathrm{kg}^{-1}$ & 100 \\
Clay & $\mathrm{g} \mathrm{kg}^{-1}$ & 120 \\
\hline
\end{tabular}

\subsection{Water Relation and Gas Exchange Measurements}

Throughout the periods of water deficit and rewatering, relative water content (RWC), photosynthesis $(A)$, transpiration rate $(E)$, stomatal conductance $(g \mathrm{~s})$, intercellular $\mathrm{CO}_{2}$ concentration ( $c$ i) were measured. The water use efficiency (WUE) was obtained by the ratio $A / g s$, and $c i / c a$ was calculated by ratio in $c i$ and $\mathrm{CO}_{2}$ atmosphere concentration $(c a)$.

Plant water status was determined by measurements of relative water content $(R W C)$. In order to obtain the $R W C$ values, leaves were weighed for fresh mass (FM) determination and then placed in glass dishes for $48 \mathrm{~h}$. After measurement of saturated mass (SM), the plant samples were dried at $70^{\circ} \mathrm{C}$ for $72 \mathrm{~h}$ to determine dry mass (DM). The RWC values were evaluated as $R W C(\%)=\left[\left(\mathrm{fw}^{-} \mathrm{dw}\right) /(\mathrm{tw}-\mathrm{dw})\right] \times 100$ (Weatherley, 1950), in which fw, dw and tw refer to fresh weight, dry weight and turgid weight, respectively.

Gas exchange measurements were taken from entirely unfolded and healthy leaves (two leaves per plant, in four plants per treatment), exposed and perpendicularly oriented to the 
sun, from young branches in the middle third of the plant, between 10:00 and 11:00 am, using a portable photosynthesis analyzer LCpro-SD (ADC Bio Scientific Ltd.). All gas exchange measurements were recorded during the typical diurnal range of air temperature, and humidity under our field conditions, and PAR flux was adjusted to $1200 \mu \mathrm{mol} \mathrm{m}^{-2} \mathrm{~s}^{-1}$.

\subsection{Data Analysis}

All experiments were performed with four replicates, and five plants per replication. Data were subjected to one-way ANOVA, and significant differences determined by the Scott-Knott test ( $\mathrm{p}<0.05$ ), using the ASSISTAT software (Silva and Azevedo, 2002).

\section{Results}

\subsection{Relative Water Content and Gas Exchange}

There was a significant difference in $R W C$ between treatments from the second day of water deficit imposition, with gradual reduction until the seventh day (Figure 1).

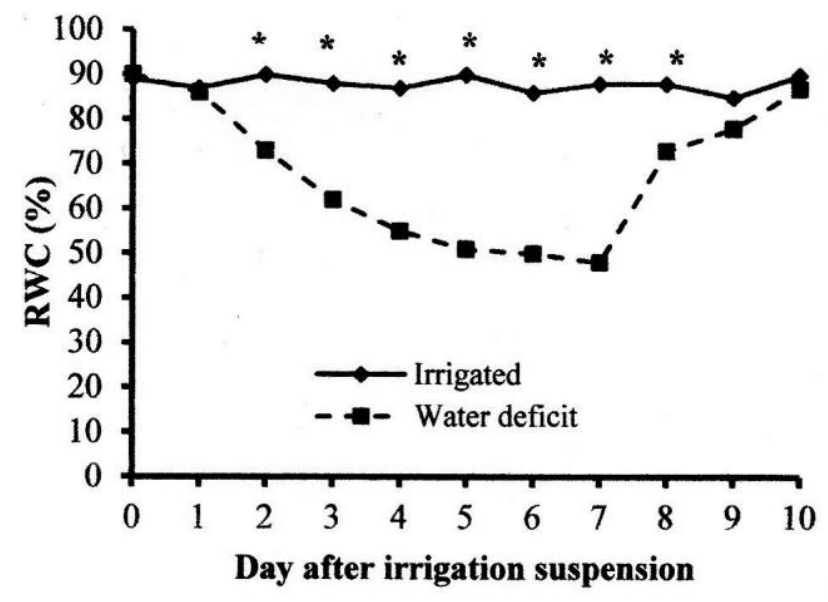

Figure 1. Relative water content $(R W C)$ of $M$. tenuiflora plants irrigated and under water deficit. The arrow indicates the day of rewatering

*Differences between treatments on the same day

While irrigated plants maintained a high $R W C(90 \%)$, plants under water deficit reached critical levels on the fourth day, with $55 \%$. This value falls to $48 \%$ on the seventh day, corresponding to almost half of the $R W C$ of irrigated plants. One day after rewatering, the plants recovered turgidity, reaching $73 \% R W C$ indicating that there was no damage to cells under low tissue hydration condition, with rapid rehydration with the resumption of water supply. Following the reduction in $R W C$, stomata were affected on the first day of water deficit, with progressive reduction of $E$ (Figure 2A), $g s$ (Figure 2B), A (Figure 2C), and increase $c i$ (Figure 2D).

On the seventh day after the beginning of the treatments, irrigated plants presented $E$ equal to $4.48 \mathrm{mmol} \mathrm{m}^{-2} \mathrm{~s}^{-1}$, while in plants under water deficit was $0.043 \mathrm{mmol} \mathrm{m}^{-2} \mathrm{~s}^{-1}$ (Figure 2A ), representing a $99 \%$ difference. On the day of irrigation suspension, the $E$ value was 3.28 


\section{Macrothink Institute ${ }^{T M}$}

mmol m $\mathrm{m}^{-2} \mathrm{~s}^{-1}$, reaching $0.043 \mathrm{mmol} \mathrm{m}^{-2} \mathrm{~s}^{-1}$, with $98.6 \%$ reduction. Despite the rapid recovery in $R W C$ (Figure 1), only on the second day after irrigation that there was an increase in $E$, but much lower than the treatment irrigated. On the last day of the evaluation, three days after the resumption of water supply, there was a total recovery in plant's transpiration.

The gs in plants under water deficit decreased progressively as the irrigation suspension period increased, reaching a value equivalent to $94 \%$ of the irrigated plants, on the last day after irrigation suspension. After resumption of irrigation, the recovery of this parameter followed the same behavior in $E$.

Regarding $A$ in irrigated plants the values ranged from 24.2 to $34.2 \mu \mathrm{mol} \mathrm{m} \mathrm{m}^{-2} \mathrm{~s}^{-1}$, while in plants under deficit the variation ranged from 21.1 to $0 \mu \mathrm{mol} \mathrm{m} \mathrm{m}^{-2}$, respectively on the first and seventh day of the beginning of the treatments (Figure 2C). On the fourth day, theoretically under moderate stress, the plants showed reductions of 54\%,76\% and $42 \%$ in $g s$, $E$ and $A$, indicating that, despite the reduction in stomatal conductance, there was little influence on $\mathrm{CO}_{2}$ assimilation (Figure 2). However, as the water deficit period increased, stomata closure increased, causing total inhibition in photosynthesis. As with $g s$ and $E$, on the third day after rehydration there was a complete recovery in $A$, reaching levels equal to those of irrigated plants, indicating that the water stress imposed was not enough to cause irreversible damage to the stomatal function and the photosynthetic apparatus.
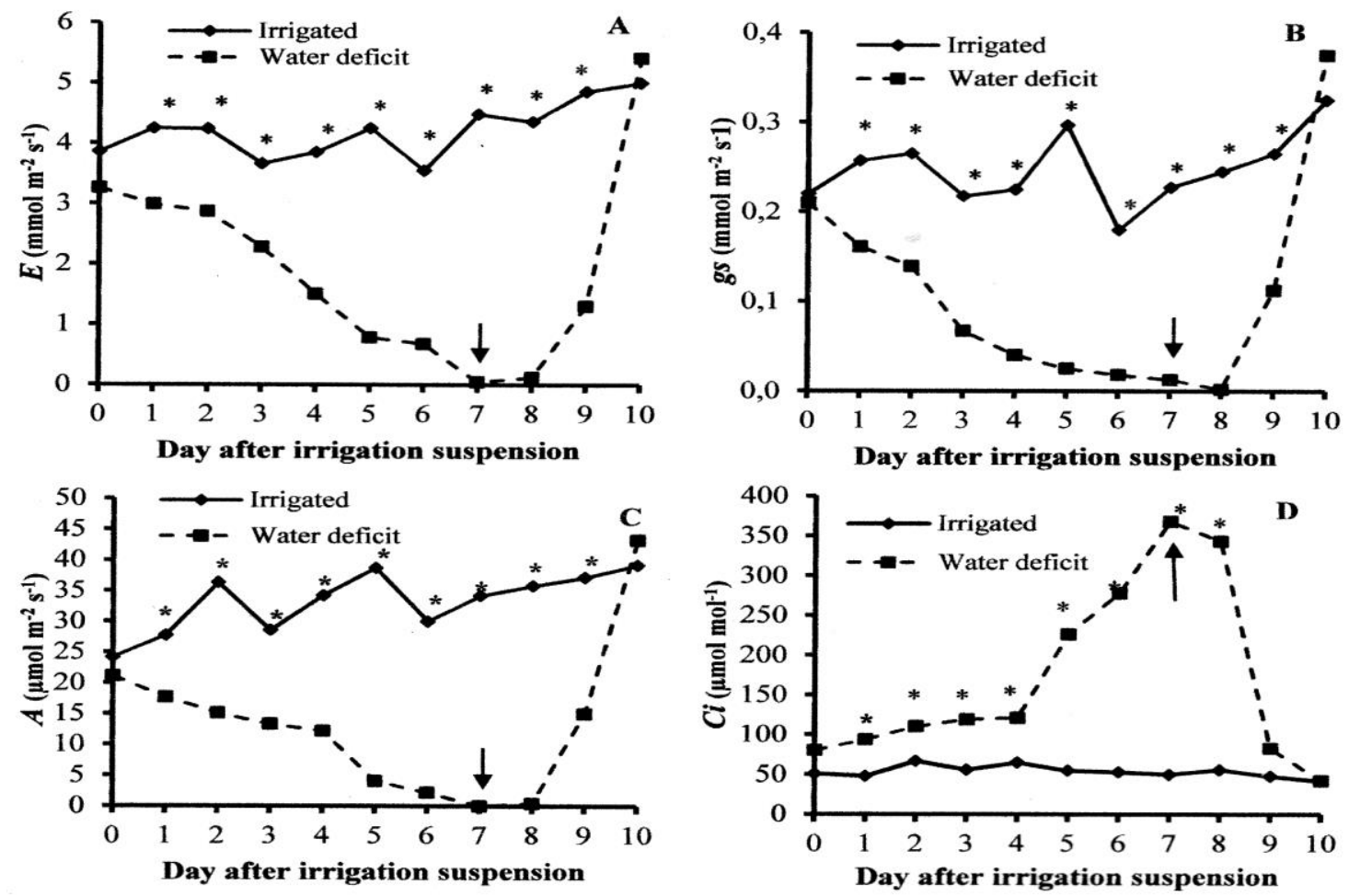

Figure 2. Transpiration $(E)$, stomatal conductance $(g s)$, photosynthesis $(A)$ and intercelular $\mathrm{CO}_{2}$ concentration $(\mathrm{Ci})$ of $M$. tenuiflora plants irrigated and under water deficit. The arrow indicates the day of rewatering

*Differences between treatments on the same day 
Irrigated plants maintained WUE between 0.1 and $0.17 \mu \mathrm{mol} \mathrm{mol}^{-1}$ (Figure 3A), while plants under water deficit increased from the second to the fourth day, and decreased until $0 \mu \mathrm{mol}$ $\mathrm{mol}^{-1}$ on the seventh day without irrigation.

Due to the behavior observed in $c i$ (Figure 2D), the $c i / c a$ ratio (Figure 3B) of irrigated plants remained almost constant, whereas in plants under water deficit increased, reaching a maximum of 1.0 on the seventh day after the start of treatments, decreasing after rewatering.
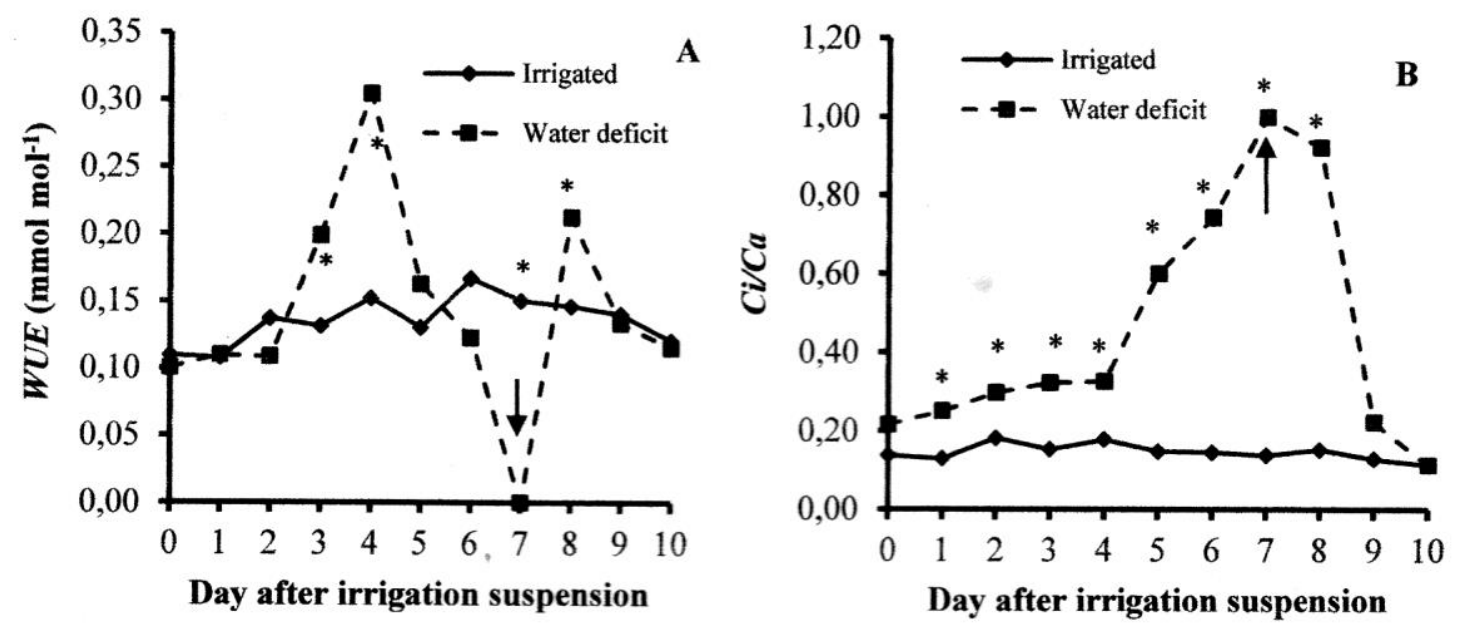

Figure 3. Water use efficiency (WUE) and $\mathrm{ci} / \mathrm{ca}$ ration of $M$. tenuiflora plants irrigated and under water deficit. The arrow indicates the day of rewatering

*Differences between treatments on the same day

\section{Discussion}

According to Pardo (2010), RWC 50\% is critical to plants, and the adequate value for well-hydrated tissues ranges from 85 to $95 \%$. However, some species adapted to arid and semiarid climate regions can reach this value without tissue death, which may be the case of M. tenuiflora plants in this research, since after the resumption of the supply of adequately restored their water status. These results agree with those found in the literature, in Handroanthus impetiginosus (Pessoa et al. 2017), Myracrodruon urundeuva (Costa et al., 2015), Hevea brasiliensis (Chen et al., 2010), and Quercus pubecens (Gallé et al. ., 2007).

The speed of response to the reduction in water availability varies by species, and the degree of this response directly affects the maintenance of plant tissue water balance. In $H$. impetiginosus seedlings, a $15 \%$ reduction in $R W C$ was observed on the second day after the water supply was suspended (Pessoa et al. 2017). These researchers also reported that at 10 days after irrigation suspension, $R W C$ in irrigated and under water deficit plants were $83 \%$ and $26 \%$, respectively, resulting in a $69 \%$ reduction. In $M$. urundeuva irrigated plants, Costa et al. (2015) observed a variation of 82 to $91 \%$, while in plants under water deficit, the $R W C$ progressively reduced until reaching the value of $70 \%$ on the 12 th day of evaluation.

The recovery of $R W C$ in $M$. tenuiflora plants after rewatering indicates that stress did not cause irreversible damage to the hydraulic conductivity of the root xylem vessels. Among the 
effects of water stress are cavitation (Holbrook et al., 2001, Otieno et al., 2005) and consequent decrease in hydraulic conductivity (Chen et al., 2010). However, the phenomenon of cavitation can be immediately neutralized after the resumption of water supply to plants, with recovery of root hydraulic conductivity (Holbrook et al., 2001, Otieno et al., 2005).

The rapid reduction in $E$ and $g s$ of plants under water deficit demonstrate the sensitivity of the stomata of this species to water deficit, constituting a survival strategy under adverse water conditions, avoiding excessive loss of tissue water and consequently death by dehydration. The fact that the stomatal mechanism was recovered indicates that the time elapsed from the imposition of water restriction did not cause irreversible damage to the stomata, enabling the recovery of its functioning after plant rehydration. When water supply decreases, guard cells respond to leaf water potential and control their water loss by decreasing transpiration (Chaves et al., 2010). These authors add that partial pressure of intercellular $\mathrm{CO}_{2}$ can control stomatal opening by supplying $\mathrm{CO}_{2}$ to chloroplast or by $\mathrm{CO}_{2}$ demand for photosynthesis. The physiological mechanisms of stomata response to water deficit are complex and not yet fully understood (Patakas et al., 2005), since they can respond to a series of stimuli, and not all of them are directly related to soil water content, as stomatal sensitivity to vapor pressure deficit (VPD) (Habermann et al., 2003). Another stimulus that may regulate the stomatal response is increased cellular abscisic acid (ABA) under water stress conditions (Harris and Outlaw, 1991) or apoplastic ABA on the surface of guard cells, which supposedly cause a reduction in turgor pressure (Assmann, 2003), which in turn leads to stomatal closure (Sousa et al., 2006). These factors make stomatal control independent or indirectly related to soil water content.

Decreased photosynthesis under water deficit conditions may occur due to stomatal factors, due to reduced stomatal conductance, restricting gas exchange between the plant and the external environment (Flexas and Medrano, 2002, Flexas et al., 2004, Farooq et al., 2009), or by non-stomatal factors, due to damage caused to the photosynthetic apparatus (Fu and Huang, 2001) as well as by decreased activity of Calvin Cycle enzymes (Monakhova and Chernyad'ev, 2004). Zhou et al. (2013) and Osakabe et al. (2014) related a close correlation between water stress and $g s$, which constitutes is one of the most important factors that leads to a decline in $A$ during drought conditions (Peeva and Cornic 2009; Zhou et al. 2013).

Under mild to moderate water deficits, stomatal closure is one of the first responses of plants, restricting water loss and carbon assimilation (Chaves et al., 2003). However, if the deficit condition persists, acclimatization responses such as growth inhibition and osmoregulation are triggered, which are key elements for maintaining the water status of the plant and therefore assimilation of the plant carbon under water scarcity (Chaves et al., 2010). In grapevine, maintenance of Calvin Cycle enzymes activity and maximum carboxylation and electron transport rates have been reported under low to moderate water availability (Souza et al., 2005). However, as stress intensifies these parameters decline especially in electron transport (Maroco et al., 2002, Souza et al., 2005), possibly as a result of decreased ATP production (Chaves et al., 2010).

The reduction in $W U E$ here observed contradicts the results obtained in other studies, where 
there was an increase in WUE under water stress conditions (Diaz-López et al., 2012, Dombroski et al., 2014). While stomatal conductance is more affected than photosynthesis under moderate water stress until the fourth day (Figures 2A and 2B), WUE has increased (Figure 3A). Elevation in $W U E$ even before complete stomatal closure is a common phenomenon in plants under water stress (Pou et al. 2008, Chen et al., 2010).

Similar to what happened in $c i$ (Figure 2D), in the middle of the water deficit period, between days three and four, the values of $\mathrm{ci} / \mathrm{ca}$ were low, meaning that there was low accumulation of $\mathrm{CO}_{2}$ in the intercellular spaces, probably because it is being used for photosynthesis, even in smaller quantities (Figure 2C). Thus, non-stomatal factors are believed to play an important role in limiting photosynthesis under water deficit conditions in black jurema plants, as gs decreased and the $\mathrm{ci} / \mathrm{ca}$ ratio increased, as reported (Bacelar et al., 2007). However, some authors state that $\mathrm{c} i$ values should be carefully analyzed, since stomata opening does not occur evenly due to irregularities in the leaf surface (Bacelar et al., 2007). In addition, $c i$ calculated from gas exchange measurements can be overestimated and lead to erroneous conclusions of non-stomatal limitation of photosynthesis (Downton et al., 1988).

\section{Conclusion}

- Mimosa tenuiflora plants respond quickly to irrigation suspension, promoting stomata closure, occuring reduction in stomatal conductance, transpiration rate and photosynthesis.

- The water use efficiency of $M$. tenuiflora plants under water deficit remains high for a short period after irrigation water restriction.

- The stress level imposed did not cause irreversible damage to cells and tissue of plants.

\section{Acknowledgement}

The authors thank the Coordenação de Aperfeiçoamento de Pessoal de Nível Superior CAPES for the financial support.

\section{References}

Araújo, E. L. (2005). Estresses abióticos e bióticos como forças, modeladoras da dinâmica de populações vegetais da caatinga. In: NOGUEIRA, R. J. M. C. et al. Estresses ambientais: danos e benefícios em plantas. Recife: Universidade Federal Rural de Pernambuco. 500p.

Assmann, S. M. (2003). OPEN STOMATA1 opens the door to ABA signalling in Arabidopsis guard cells. Trends Plant Science, 8, 151-153.

https://doi.org/10.1016/S1360-1385(03)00052-9

Azevêdo, S. M. A. et al. (2012). Crescimento de plântulas de jurema preta (Mimosa tenuiflora (Wild) Poiret) em solos de áreas degradadas da caatinga. Engenharia Ambiental, 9, 150-160.

Bacelar, E. A. et al. (2007). Changes in growth, gas exchange, xylem hydraulic properties and water use efficiency of three olive cultivars under contrasting water availability regimes. Environmental and Experimental Botany, 60, 183-192.

https://doi.org/10.1016/j.envexpbot.2006.10.003 


\section{Ml Macrothink}

Journal of Agricultural Studies

ISSN 2166-0379

2019, Vol. 7, No. 4

Bakke, I. A. et al. (2006). Water and sodium chloride effects on Mimosa tenuiflora (Willd.) Poiret seed germination. Revista Caatinga, 19, 261-267.

Chaves, M. M. et al. (2010). Grapevine under deficit irrigation: hints from physiological and molecular data. Annals of Botany, 105, 661- 676. https://doi.org/10.1093/aob/mcq030

Chaves, M. M., Maroco, J. P., \& Pereira, J. S. (2003). Understanding plant response to drought - from genes to the whole plant. Functional Plant Biology, 30, 239-264.

https://doi.org/10.1071/FP02076

Chen, J. W. et al. (2010). Gas exchange and hydraulics in seeedlings of Hevea brasiliensis during water stress and recovery. Tree Physiology, 30, 876-885.

https://doi.org/10.1093/treephys/tpq043

Choudhury, F. K. et al. (2017). Reactive oxygen species, abiotic stress and stress combination. The Plant Journal, 90, 856-867. https://doi.org/10.1111/tpj.13299

Costa, A. S. et al. (2015). Respostas fisiológicas e bioquímicas de plantas de aroeira (Myracrodruon urundeuva Allemão) ao déficit hídrico e posterior recuperação. Irriga, 20, 705-717. https://doi.org/10.15809/irriga.2015v20n4p705

Diaz-López , L. D. et al. (2012). The tolerance of Jatropha curcas seedlings to NaCl: An ecophysiological analysis. Plant Physiology and Biochemistry, 54, 34-42.

https://doi.org/10.1016/j.plaphy.2012.02.005

Dombroski, J. L. D. et al. (2014). Ecophysiology of water stressed Handroanthus impetiginosus (Mart. ex DC) Mattos seedlings. Scientia Forestalis, 42, 155-163.

Downton, W. J. S., Loveys, B. R., Grant, W. J. R. (1988). Non-uniform stomatal closure induced by water stress causes putative non-stomatal inhibition of photosynthesis. New Phytologist, 110, 503-509. https://doi.org/10.1111/j.1469-8137.1988.tb00289.x

Farooq, M. et al. (2009). Improving the drought tolerance in rice (Oryza sativa L.) by exogenous application of salicylic acid. Journal of Agronomy \& Crop Science, 195, 237-246. https://doi.org/10.1111/j.1439-037X.2009.00365.x

Fernandes, E. M. et al. (2015). Respostas fisiológicas de clones de eucalipto cultivados em casa de vegetação sob deficiência hídrica. Ciência Rural, 45, 29-34.

https://doi.org/10.1590/0103-8478cr20120152

Flexas, J. et al. (2004). Diffusive and metabolic limitations to photosynthesis under drought and salinity in C3 plants. Plant Biology, 6, 269-279. https://doi.org/10.1055/s-2004-820867

Flexas, J., \& Medrano, H. (2002). Drought-inhibition of photosynthesis in C3 plants: stomatal and non-estomatal limitations revisited. Annals of Botany, 89, 183-189. https://doi.org/10.1093/aob/mcf027

Fu, J., \& Huang, B. (2001). Involvement of antioxidants and lipid peroxidation in the adaptation of two cool-season grasses to localized drought stress. Environment and Experimental Botany, 45, 105-112. https://doi.org/10.1016/S0098-8472(00)00084-8 
Gallé, A., Haldimann, P., \& Feller, U. (2007). Photosynthetic performance and water relations in young pubescent oak (Quercus pubescens) trees during drought stress and recovery. New Phytologist, 174, 799-810. https://doi.org/10.1111/j.1469-8137.2007.02047.x

Gouvêa, P. S., \& Marenco, R. A. (2018). Is a reduction in stomatal conductance the main strategy of Garcinia brasiliensis (Clusiaceae) to deal with water stress? Theoretical and Experimental Plant Physiology, 30, 321-333. https://doi.org/10.1007/s40626-018-0127-0

Guimarães, S. O. et al. (2016). Projeções de Mudanças Climáticas sobre o Nordeste Brasileiro dos Modelos do CMIP5 e do CORDEX. Revista Brasileira de Meteorologia, 31, 337-365. https://doi.org/10.1590/0102-778631320150150

Habermann, H. et al. (2003). Gas exchange rates at different vapor pressure deficits and water relations of 'Pera' sweet orange plants with citrus variegated chlorosis (CVC). Science Horticulture, 98, 233-245. https://doi.org/10.1016/S0304-4238(02)00228-5

Harris, M. J., \& Outlaw, W. H. (1991). Rapid adjustment of guard cell abscisic acid levels to current leaf-water status. Plant Physiology, 95, 171-173. https://doi.org/10.1104/pp.95.1.171

Holbrook, N. M. et al. (2001). In vivo observation of cavitation and embolism rapir using magnetic resonance imaging. Plant Physiology, 126, 27-31.

https://doi.org/10.1104/pp.126.1.27

Maroco J. P. et al. (2002). Limitations to leaf photosynthesis in field-grown grapevine under drought - metabolic and modelling approaches. Functional Plant Biology, 29, 451-459. https://doi.org/10.1071/PP01040

Monakhova, O. F., \& Chernyad'ev, L. I. (2004). Effects of cytokinin preparations on the stability of the photosynthetic apparatus of two wheat cultivars experiencing water deficiency. Applied Biochemical and Microbiology, 40, 573-580.

https://doi.org/10.1023/B:ABIM.0000046993.38857.3e

Moura, A. R. et al. (2016). Relações hídricas e solutos orgânicos em plantas jovens de Jatropha curcas L. sob diferentes regimes hídricos. Ciência Florestal, 26, 345-354. https://doi.org/10.5902/1980509822735

Nio, S. A. et al. (2011). Pattern of solutes accumulation during leaf osmotic adjustment as related to duration of water deficit for wheat at the reproductive stage. Plant Physiology and Biochemistry, 49, 1126-1137. https://doi.org/10.1016/j.plaphy.2011.05.011

Oliveira, A. K. M., \& Gualtieri, S. C. J. (2017). Gas exchange and tolerance degree in young plants of Tabebuia aurea 'Paratudo', under flooding. Ciência Florestal, 27, 181-191. https://doi.org/10.5902/1980509826457

Oliveira, M. K. T. et al. (2016). Desenvolvimento inicial de Erythrina velutina sob restrição hídrica. Pesquisa Florestal Brasileira, 36, 481-488.

https://doi.org/10.4336/2016.pfb.36.88.1261 
Osakabe, Y. et al. (2014). Response of plants to water stress. Front Plant Science, 5, 1-8. https://doi.org/10.3389/fpls.2014.00086

Otieno, D. O. et al. (2005). Physiological and morphological responses to water stress in two Acacia species from contrasting habitats. Tree Physiology, 25, 361-371.

https://doi.org/10.1093/treephys/25.3.361

Pardo, J. M. (2010). Biotechnology of water and salinity stress tolerance. Current Opinion in Biotechnology, 21, 185-196. https://doi.org/10.1016/j.copbio.2010.02.005

Patakas, A., Noitsakis, B., \& Chouzouri, A. (2005). Optimization of irrigation water use in grapevines using the relationship between transpiration and plant water status. Agriculture Ecosystems \& Environment, 106, 253-259. https://doi.org/10.1016/j.agee.2004.10.013

Paterno, G. B., Siqueira Filho, J. A., \& Ganade, G. (2016). Species-specific facilitation, ontogenetic shifts and consequences for plant community succession. Journal of Vegetation Science, 27, 606-615. https://doi.org/10.1111/jvs.12382.

Peeva, V., \& Cornic, G. (2009). Leaf photosynthesis of Haberlea rhodopensis before and during drought. Environmental and Experimental Botany, 65, 310-318.

https://doi.org/10.1016/j.envexpbot.2008.09.009

Pessoa, J. L., Freire, A. L. O., \& Costa, A. S. (2017). Gas exchange of Handroanthus impetiginosus (Mart. ex DC) Mattos plants under water stress and rehydration. Revista de Ciências Agroveterinárias, 16, 269-276. https://doi.org/10.5965/223811711632017269

Pou, A. et al. (2008). Adjustments of water use efficiency by stomatal regulation during drought and recovery in the drought-adapted Vitis hybrid Richter-110 (V. berlandieri $\mathrm{x} V$. rupestris). Physiologia Plantarum, 134, 313-323.

Santos, A. R. F., Silva-Mann, R., \& Ferreira, R. A. (2011). Restrição hídrica em sementes de jenipapo (Genipa americana L.). Revista Árvore, 35, 213-220.

https://doi.org/10.1590/S0100-67622011000200006

Silva, F. A. S., \& Azevedo, C. A. V. (2002). Versão do programa computacional Assistat para o sistema operacional Windows. Revista Brasileira de Produtos Agroindustriais, 4, 71-78. https://doi.org/10.15871/1517-8595/rbpa.v4n1p71-78

Sircelj, H. et al. (2007). Detecting different levels of drought stress in apple trees (Malus domestica Borkh.) with selected biochemical and physiological parameters. Scientia Horticulturae, 113, 362-369. https://doi.org/10.1016/j.scienta.2007.04.012

Sousa, T. A., Oliveira, M. T., \& Pereira, J. M. (2006). Physiological indicators of plant water status of irrigated and non-irrigated grapevines grown in a low rainfall area of Portugal. Plant and Soil, 282, 127-134. https://doi.org/10.1007/s11104-005-5374-6

Souza, C. R. et al. (2005). Control of stomatal aperture and carbon uptake by deficit irrigation in two grapevine cultivars. Agriculture, Ecosystems and Environment, 106, 261-274. https://doi.org/10.1016/j.agee.2004.10.014 


\section{Macrothink}

Journal of Agricultural Studies

ISSN 2166-0379 2019, Vol. 7, No. 4

Weatherley, P. E. (1950). Studies in the water relations of cotton plant. I. The field measurements of water deficits in leaves. New Phytologist, 49, 81-97.

https://doi.org/10.1111/j.1469-8137.1950.tb05146.x

Zhou, S. et al. (2013). How should we model plant responses to drought? An analysis of stomatal and non-stomatal responses to water stress. Agriculture and Forest Meteorology, 182, 204-214. https://doi.org/10.1016/j.agrformet.2013.05.009

\section{Copyright Disclaimer}

Copyright for this article is retained by the author(s), with first publication rights granted to the journal.

This is an open-access article distributed under the terms and conditions of the Creative Commons Attribution license (http://creativecommons.org/licenses/by/4.0/). 